第 2 回日本熱帯生態学会年次大会シンポジウム

\title{
熱帯におけるバイオダイバーシティの諸問題
}

\section{Biodiversity; Vital Problems of Tropical Nature and Human Beings}

\author{
(於千葉幕張メッセ, 1992,6,20)
}

湿潤で一年中高温な熱帯地域は，地球上で最も豊かな生物相をはぐくんでいます。その熱帯地 域の生物相の多様性，それを維持しているメカニズムに関しては最近多くの研究が産み出されて います。また熱帯圏は森林が生育する湿潤な地域だけではありません。サバンナから砂漠に到る 乾燥環境も存在しています。それぞれの熱帯地域には，長い地史的時間をかけて特有の生物群が 進化してきましたし，環境の変動はそれら生物群のさらなる分化をもたらしただけでなく，絶滅 も引き起こしてきました。生物相の熱帯での高い多様性は，一定面積に分布する生物の種数の多 さで代表されていますが，なぜ熱帯では生物の種数が多くなるかについては，言い換えれば熱帯 でのバイオダイバーシティの高さの原因については，確かな考えは確立されていません。この基 本的な問題については，分類学と生態学のそれぞれの立場で議論が展開されます。

また私達，ヒトはこの熱帯の多様性に満ちた環境の中でも生活をしています。マレーシア森林 地域での森住みのヒト，より乾燥した地域を含むニューギニア低地のヒト，そしてアフリカの狩 猟採集民についての，それぞれの環境の中で生きているヒトの環境との関わりかた，生ざまをみ ると，高いバイオダイバーシティのなかで，その環境に依存し，あるいはその環境を改変しなが らも多様性を維持する生き方があることが示されます。

このシンポジウムでは，問題とする対象が「熱帯のバイオダイバーシティ」だけではなく，そ れの破壊や維持にヒトがどのように関わり合っているかの側面も明らかにされることが目指され ます。狩猟採集や農耕の初期的段階の生業を営んでいる熱帯のヒトの生きざまは，急速に進行し ている熱帯域の生物相の破壊に対しても，多くの示唆を与えてくれるでしょう。

しかし何よりも，このシンポジウムがダイバーシティに満ちた話題の提供と議論の展開の場に なることを願っています。 


\section{シンポジウム 熱帯におけるバイオダイバーシティの諸問題}

A Simposium on 'Biodiversity; Vital Problems of Tropical Nature and Human Beings' organized by the Japan Society of Tropica Ecology

(於千葉幕張メッセ, 1992, 6,20)

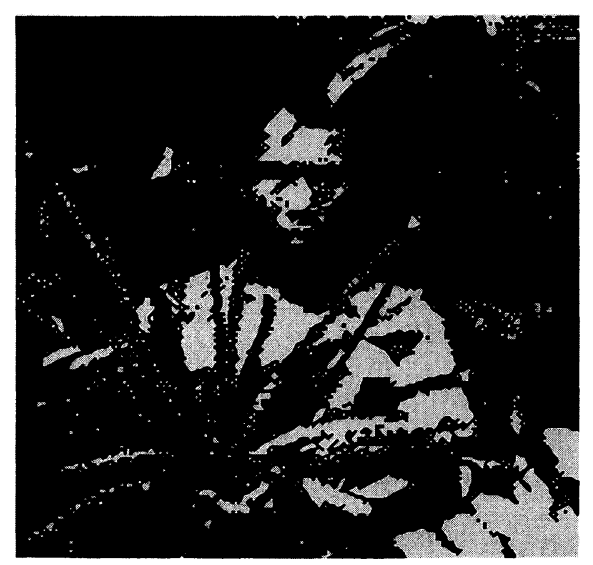

森の中のブナン族 サラワク第4省カクス上流

座長堀田 満（鹿巟島大理学部）

依田恭二（大阪市大理学部）

加藤 雅啓 (東大理学部小石川植物園) 熱帯多雨林はなぜ種の多様性が高いか一分類学の立場 山倉 拓夫 (大阪市大理学部) 熱帯多雨林はなぜ種の多様性が高いか一生態学の立場 山田 勇 (京大東南アジア研)＼cjkstart束南アジア熱帯多雨林生態系とヒト 大塚 柳太郎 (東大医学部) ニューギニア低地におけるミクロな環境変動とヒトの適応機構 市川光雄 (京大アフリカ研) 䏠）狩猟採集民の森林利用における多様性と多重性

第 2 回日本熱帯生態学会のシンポジウムの記録を特集しました。前回と同様に討論のテープおこしは愛 媛大学の遲沢克也さんに㹉いいたしました。また, 海外調査など多忙な中で原稿をまとめていただいた 皆様方には心から感謝いたしております。残念なことに「多様性」について生態学の立場からお話しいた だいた山倉拓夫氏の原稿がサラワクの調査にでかけられるまでに完成せず，この号には掲載ができなくな りました。不完全な形の「記録」になったことを編集委員会としておわびいたします。 